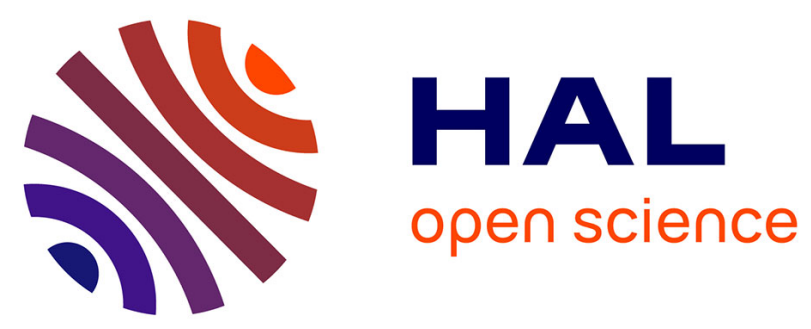

\title{
MAGNETIZATION, ELECTRICAL RESISTIVITY AND THE NON-OCCURENCE OF SUPERCONDUCTIVITY IN NiH
}

D. Mclachlan, I. Papadopoulos, T. Doyle

\section{- To cite this version:}

D. Mclachlan, I. Papadopoulos, T. Doyle. MAGNETIZATION, ELECTRICAL RESISTIVITY AND THE NON-OCCURENCE OF SUPERCONDUCTIVITY IN NiH. Journal de Physique Colloques, 1978, 39 (C6), pp.C6-430-C6-431. 10.1051/jphyscol:19786193 . jpa-00217610

HAL Id: jpa-00217610

https://hal.science/jpa-00217610

Submitted on 1 Jan 1978

HAL is a multi-disciplinary open access archive for the deposit and dissemination of scientific research documents, whether they are published or not. The documents may come from teaching and research institutions in France or abroad, or from public or private research centers.
L'archive ouverte pluridisciplinaire HAL, est destinée au dépôt et à la diffusion de documents scientifiques de niveau recherche, publiés ou non, émanant des établissements d'enseignement et de recherche français ou étrangers, des laboratoires publics ou privés. 


\title{
MAGNETIZATION, ELECTRICAL RESISTIVITY AND THE NON-OCCURENCE OF SUPERCONDUCTIVITY IN NiH
}

\author{
D.S. Mchachlan, I. Papadopoulos and T.B. Doyle. \\ University of the Witwatersrond, Johanesburg, South Africa.
}

Résumé.- Les mesures d'aimantation montrent qu'à $4 \mathrm{~K}$, NiH est un système continu à deux phases $(\alpha-\beta)$ pour tout $\mathrm{x}(\mathrm{x}=\mathrm{H} / \mathrm{Ni})$. Les résultats de la résistivité de phonon des échantillons $\mathrm{NiH}$ sont bien représentés par une fonction de Grúneisen avec $\theta_{\mathrm{D}}=365 \mathrm{~K}$. Aucune contribution à la rễs istivité de la part des phonons optiques de basse énergie ${ }^{P} a$ été observée et l'on peut déduire que $\mathrm{NiH} \mathrm{n}^{\prime}$ est probablement pas un supraconducteur.

\begin{abstract}
Magnetization measurements show that, at $4 \mathrm{~K}$, NiH is a continuous two phase $(\alpha-\beta)$ system for all $x(x=H / N i)$. The phonon resistivity results for $\mathrm{NiH}_{x=3}$ samples fit a Grllneisen function with $\theta_{D} \simeq 365 \mathrm{~K}$. No contribution to the resistivity by low lying optical phonons is observed and it is concluded that $\mathrm{NiH}$ is probably not a superconductor.
\end{abstract}

Previous magnetization measurements $/ 1 /$ made at room temperature have shown that the ferromagnetic saturation moment $I_{S}(x)$ for $\mathrm{NiH}_{x}(x=H / N i)$ decreases with $x$ and vanishes for $x$ in the range 0.6 $\hat{x} \leqslant 0.85$. The question then naturally arises whether $\mathrm{NiH}_{x}$, like $\mathrm{PdH}_{\mathrm{x}}$, may not also be a superconductor for sufficiently large $x$. In PdH it has been established that the superconducting exchange interaction primarily involves optical phonons $/ 2,3 /$. It is therefore of some interest to investigate the possibility of a low lying optical phonon band in $\mathrm{NiH}_{\mathrm{x}}$. To this end and to investigate further the magnetization of $\mathrm{NiH}_{x}$ resistivity measurements in the range $1.5 \mathrm{~K} \lesssim T \lesssim 200 \mathrm{~K}$ and magnetization measurements at $4 \mathrm{~K}$ were made on foil specimens of various x.

The specimens used in this work were produced by electrolytically charging $99.99+$ pure $\mathrm{Ni}$ foils ( $\simeq 10.0 \mu \mathrm{m}$ thick) with hydrogen at $0^{\circ} \mathrm{C}$ or room temperature. After preparation the samples were kept at $140 \mathrm{~K}$ or lower and stored, handled and mounted for experimental measurements under liquid nitrogen The hydrogen content $x$ was determined from thermoelectric power measurements at approximately $140 \mathrm{~K}$ where it is known that the thermoelectric power varies linearly /4/ with $x$. These results were checked against chromotographic measurements in some of the specimens.

Magnetization measurements were made using a Foner (vibrating sample) magnetometer, which has the facility that suitably mounted specimens can be quenched to $4 \mathrm{~K}$ in the magnetometer within seconds. For each value of $x, I(H, T=4 k)$ measurements (with $\mathrm{H}$ in the range $\mathrm{H} \leqslant \pm 20 \mathrm{kOe}$ ) were made on the hydrogenated specimen and then again after the specimen had been dehydrogenated. (Dehydrogenation was achieved by removing the specimen from the magnetometer and annealing it in situ in its holder for 60 minutes at $\left.110^{\circ} \mathrm{C}\right)$. Using the expansion $\mathrm{I}(\mathrm{H})=$ $\mathrm{I}_{\mathrm{S}}\left[1-\mathrm{a} / \mathrm{H}-\mathrm{b} / \mathrm{H}^{2}\right]$, for $\mathrm{H}$ in the range $2.5 \mathrm{kOe} \delta \mathrm{H}$ $\lesssim 20 \mathrm{kOe}$ to obtain $\mathrm{I}_{S}$, the reduced saturation moment $I_{S}\left(\mathrm{NiH}_{x}\right) / I_{S}(\mathrm{Ni})$ was calculated. These results for $I_{S}\left(\mathrm{NiH}_{X}\right) / I_{S}(\mathrm{Ni})$ are shown as a function of $x$ in figure 1 and it is apparent, within experimental error, that $I_{S}(x)$ decreases with $x$ as $(1-x)$.

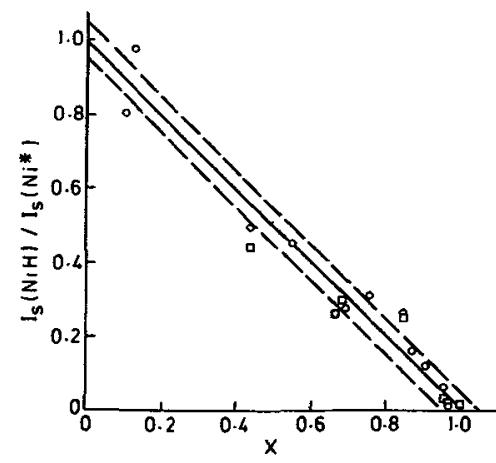

Fig. 1 : The ratio $I_{S}(\mathrm{NiH}) / I_{S}(\mathrm{Ni})$ as a function of hydrogen content $(x)$.

The room temperature and $4 \mathrm{KI}_{\mathrm{S}}(\mathrm{x})$ results can be readily understood in terms of the nickel-hydride phase-diagram. It is known from $\mathrm{x}$-ray $/ 5 /$ and electrochemical /6/ measurements that at room temperature $\mathrm{NiH}_{x}$ can exist in three equilibrium phase states, viz; with increasing $x$, an $\alpha$ phase, an 
$\alpha+\beta$ phase mixture and a pure $\beta$ phase. The $\alpha \rightarrow \alpha+\beta$ phase boundary occurs at $x \leqslant 0.03 / 6 /$ and the $\alpha+\beta \rightarrow$ $\beta$ boundary for $0.65 \hat{\imath} \leqslant \hat{n} 0.85 / 5,6 /$. As the temperature decreases the $\alpha+\beta \rightarrow \beta$ boundary can be expected to move towards $1,(x z .9$ at $T=240 \mathrm{k} / 4 /)$. At $T=4 \mathrm{~K}$ the $\alpha+\beta$ mixed phase could then, as observed, extend over the entire range $0 \leq x \leq 1$. In practice because of the reduced mobility of the hydrogen at low temperatures equilibrium conditions will probab1y not be obtained. In the present magnetization experiments at $4 \mathrm{~K}$ no sign of incipient superconductivity was detected even for $x \simeq 1$ where the $\beta$ phase predominates.

The electrical resistivity measurements $\rho(T)$ were made, using a four probe technique and D.C. current of $100 \mathrm{~mA}$, in a temperature range $1.5 \mathrm{~K} \delta \mathrm{T} \hat{~}$ $200 \mathrm{~K}$, after initially quenching the specimens for $77 \mathrm{~K}$ to $4 \mathrm{~K}$. Temperature measurements were made using a gold $(0.06 \%$ Iron)-constantan thermocouple (which had been calibrated against a platinum resistance thermometer) in close thermal contact with the specimen. The $\rho(T)$ results shown in figure 2 for a specimen with $\mathrm{x}=0.985$ are similar to those for a spe cimen with $x=0.933$. The upper curve shows the $\rho(T)$ behaviour after the initial quench. At approximately $110 \mathrm{~K}$, where the hydrogen becomes significantly mobile, there is apparently some configurational redistribution of the hydrogen - probably towards equilibrium. After continuing to heat the specimen to 180 $\mathrm{K}$ and then requenching to $4 \mathrm{~K}$ the lower curve is obtained for increasing temperatures. The best fits to the experimental results using the Grineisen function (solid line) were obtained with $s-d$ and optical ban phonon scattering terms insignificantly small or neglected. The Debye temperatures $\theta_{D}$ for the two solid curves are apparently different, with that of the lower curve $\left(\theta_{D} \simeq 366 \mathrm{~K}\right)$ lower than $\theta_{D}$ for pure Ni $\left(\theta_{D} \simeq 390 \mathrm{~K}\right)$, tending towards $\theta_{D}$ for $\mathrm{Cu}(310 \mathrm{~K})$. The upper, probably non-equilibrium curve, has a $\theta_{D}$ of $345 \mathrm{~K}$.

The most significant aspect of the present results is however the apparent absence, for $T \lesssim 180$ $\mathrm{K}$, of a marked contribution to $\rho(\mathrm{T})$ in $\mathrm{NiH}$ due to optical phonon scattering. In PdH .995 the contribution to the resistivity by the optical phonons becomes noticeable between $80 \mathrm{~K}$ and $100 \mathrm{~K}^{2}$. In $\mathrm{NiH}$ the points at about $200 \mathrm{k}$, may indicate the start of a contribution by the optical phonons, this allows us to say $\theta_{\mathrm{E}}(\mathrm{NiH}) \geq 1.8 \theta_{E}(\mathrm{PdH})^{2} \geq 990 \mathrm{~K}$. Thus if only the dominant optical phonon-electron exchange interaction $/ 2,3 /$ is considered we can take $T_{C}=\theta_{E}$ exp $\left(-1 / \lambda_{\text {eff }}\right)$ where $\lambda_{\text {eff }}=\lambda-\mathrm{u}^{*} \simeq \mathrm{N}(0) \mathrm{I}^{2} /\left(\mathrm{M}_{\mathrm{E}}^{2}\right)$.

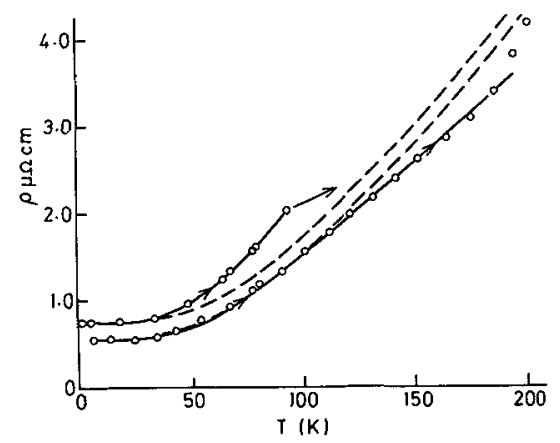

Fig. 2 : shows the best fit of the Grlneisen function to the experimental resistivity points for a sample with $x=.985$. The dashed lines show the temperature dependent resistivity of pure nickel.

Assuming $N(0) I^{2} / M$ is the same in $\mathrm{NiH}$ and $\mathrm{PdH}$ then $T_{c}(\mathrm{NiH})=\mathrm{T}_{\mathrm{c}}(\mathrm{PdH})\left(\theta_{\mathrm{E}}(\mathrm{NiH}) / \theta_{E}(\mathrm{PdH})\right) \exp -\left(\theta_{\mathrm{E}}^{2}(\mathrm{NiH}) / \theta_{\mathrm{E}}^{2}\right.$ $(\mathrm{PdH})$ ), which taking $\mathrm{T}_{c}=10 \mathrm{~K}$ for $\mathrm{PdH}$ gives $\mathrm{T}_{c}(\mathrm{NiH})$ $<0.01 \mathrm{~K}$. A more accurate calculation based on the equations of reference $/ 6 /$, which include the acoustic phonon contribution, gives $\mathrm{T}_{\mathrm{c}}(\mathrm{NiH})<0.003 \mathrm{~K}$.

\section{$\underline{\text { References }}$}

/1/ See for instance : Kozlowski, L., and Kubiak, S.T., Phys. Stat. So1. 3 (1963) K177.

/2/ McLachlan, D.S., Mailfert, R., Burger, J.P. and Souffache, B., Solid State Commun 17 (1975) 281

/3/ Burger, J.P. and McLachlan, D.S., J. Physique (Paris) 37 (1976) 1227.

/4/ Skoskiewicz, T., Phys. Stat. Sol. $\underline{6}$ (1971) 29

15/ See for instance : Boniszewski, T. and Smith, G.C., J. Phys. Chem. Solids 21 (1961) 115.

/6/ Baranowski,·B., and Szlarska-Smialowska, Z., Electrochemica Acta 9 (1964) 1497. 